\title{
Impact of globalization on the development of social entrepreneurship in Latvia
}

\author{
Silva Jeromanova-Maura ${ }^{1}$, Rosita Zvirgzdina ${ }^{1 *}$ \\ ${ }^{1}$ Turiba University, Department of Commerce, Graudu street 68, Riga, Latvia, LV 1058
}

\begin{abstract}
Research background: Since April 1, 2018, the Law on Social Entrepreneurship has been in force in Latvia. Unfortunately, the relatively slow preparation and adoption of the law did not bring any benefits to social enterprises (Jeromanova-Maura et al., 2019). Few social enterprises have recently been set up, operating in a small number of business sectors. Various financial support instruments are available to social enterprises, which could promote the establishment of a social enterprise, but the negative attitude of society and understanding of people with special needs is an obstacle to the establishment of new social enterprises. It is in the interests of local governments to give more support to social entrepreneurship in their region.

The aim of the article: to study and analyze the processes that have contributed to the faster development of social entrepreneurship and the impact of globalization on the development of social entrepreneurship in Latvia during the last couple of years. To achieve this, the authors have studied the experiences of different countries in the development of social entrepreneurship, focusing on the EU Member States and how globalization has affected the development of social entrepreneurship in each country.

Methods: The study uses methods of analysis and synthesis, methods of deduction and induction, as well as methods of logical approach. However, appropriate quantitative methods are used to process the data obtained.

Findings \& Added Value: The paper aims to assess the impact of globalization on social entrepreneurship as well as the impact of Covid on the creation and development of social enterprises.
\end{abstract}

Keywords: globalisation; social enterprise; development

JEL Classification: $L 26 ; L 30 ; L 31$

\footnotetext{
* Corresponding author: rosita@turiba.lv
} 


\section{Introduction}

The problems caused by COVID were a good reason for us to understand in Latvia how united the whole world is in problems, and thanks to modern technologies, everyone can participate everywhere from any part of the world. In view of the global economic crisis, the social aspects of globalization are even more important for development and poverty reduction. In order to combat the crisis, it is essential to increase the level of social protection, finance social safety nets and use a decent work programme. Finally, Latvians are aware of the role and impact of globalization. Until now, Latvia was very skeptical about globalization, seeing it as a loss of freedom of rights, because the newly regained independence had remained in everyone's memory. Globalization was therefore perceived as a threat.

The aim is study the impact and role of globalization in changing public opinion from denying social enterprises to a supportive, collaborative attitude and understanding of the importance of social entrepreneurship, both in terms of human rights and economic impact.

One of the objectives is to raise public awareness of diversity management, of changing thinking and attitudes towards people with disabilities and their role in society.

\section{Methods}

Research methodology and methods: In order to study the impact of globalization on social entrepreneurship in Latvia, the most information can be obtained by visiting social enterprises, interviewing specialists, participating in various seminars, conferences, working groups in ministries, actively participating in the daily processes of entrepreneurs, to observe dynamics, development, identify problems and, together with entrepreneurs, state and local government employees, representatives of the social entrepreneurship association, to seek new solutions for the development of social entrepreneurship Latvia.

\section{Results and Discussion}

\subsection{Impact of globalisation}

Globalization creates new job opportunities, but it may also create unemployment. Managing of globalization, which to bring best impact in economy and life quality, is a priority for the EU as it seeks to build a more social Europe to help the unemployed find new jobs and employ the people with special needs and all from groups of the socially vulnerable.

The number of jobs directly or indirectly provided by EU exports to countries outside the Union increasing. In 2017, the number was 36 million, 2020 it has already increased to 41 million. On average, every billion EU exports support around 13000 jobs in the EU (Strautins, 2020).

Job opportunities are not offered solely by export companies. They also occur in companies that supply them with goods and services. Thanks to the EU's single market, many jobs depend on exports from other EU countries to third countries.

The share of highly skilled workers in export-related jobs is increasing and export-related jobs are on average $12 \%$ better paid than other jobs (Strautins, 2020).

We argue that increased attention to primary stakeholders' signals affects both positively and negatively managers' capacity to analyze causal mechanisms in past acquisitions, draw inferences from them, and apply these inferences to subsequent acquisitions (Bettinazzi \& Zollo, 2021). 
International trade and the globalization process have great potential to boost employment and job opportunities within and outside the EU. However, it should be noted that increased global competition may threaten human rights, for example by promoting the exploitation of workers. As the European Union's priority in its external relations is to defend democracy and human rights, the EU uses trade policy to promote and protect human rights in third countries through preferential trade agreements, as well as unilateral trade restrictions (Strautins, 2020).

The growth of modern economic systems has generated more numerous, complex and urgent social challenges (White, 2021).

Despite the social innovation being defined and interpreted differently, it provides the social benefits for both local community and/or society in general.

Almond et al. (2011) suggest that different skills and personality traits might help predict different outcomes, with cognitive ability being more important for complex tasks, while personality is shown to be more important for job performance (Laajaj \& Macours, 2021).

Nowadays, social innovations, particularly in the rural areas, focus on successful solution of different social, economic, political and environmental issues. The social benefits, for instance, reduce the threat of climate change, maintain the biodiversity, ecosystems and landscapes; offer fresh and healthy local food etc., can be provided by the social innovations based on the agricultural production and other rural activities (Jeromanova-Maura et al., 2018).

Under the influence of globalization, after Latvia's accession to the European Union, branches of several large companies - offices and also production facilities - were relocated to Latvia. One of the reasons was the availability of labor - the attitude of employees towards work, the level of education, the work culture and, undeniably, cheaper labor costs.

This gave Latvians an opportunity to get to know the culture of companies of other countries, to acquire knowledge in practice and to create their own companies.

The workforce needed in the production facilities was less educated, foreign companies, based on their experience, created jobs for people with special needs, it was a good example for our entrepreneurs how to involve people with short needs in the labor market.

It's a big challenge for entrepreneurs to find the right people to motivate them to get their goals together.

It is commonly assumed that highly successful entrepreneurs are more confident and persistent than most others. The key differences had more to do with the quality of their motivation. The most successful entrepreneurs were the ones most determined to achieve a long -term goal that was deeply meaningful to them. Accordingly, they tended to be more systematic in the way they searched of opportunities, anticipated obstacles, monitored results, and planned ahead (Bornstein, 2007).

\subsection{The negative impact of globalization on employment}

Globalization increases competition between businesses, which can lead to business closures, relocations and job losses. The most vulnerable sectors in the EU are mostly made up of lowskilled workers, there are differences in sectors, with the most unemployed in sectors where more manual labor and lower education levels of workers - including textiles, clothing, footwear and leather, metalworking and finished metal products, as well as manufacturing. Manufacturing is the sector most exposed to relocation, as competition is created by lowwage countries.

Globalisation is failing companies that are unable to compete on the world market, even though they have been sufficiently successful on the domestic market.

Statistics show that $40 \%$ of start-ups do not exceed the 10 -year of work. If you look at the success facts from a historical perspective, around. Turn of the 19 And 20 century, these were 
financial capital, expansion of production, about the middle of the 20 century, these were the advantages of technology, patents, but at the turn of the 20. And 21. Century, it is the performance, creativity, talent, aspiration, hope and excitement of people. Today at the center of organization is a person (Zīlite, 2013).

Globalization bring a lot of new technologies, at the same time decrease amount of employes and first who lost the job is older generation, as baby boomer generation.

As baby boomers reach retirement age, demographic pressures on public programs may cause policy makers to cut benefits and encourage employment at later ages. But how much demand exists for older workers? This paper reports on a field experiment to determine hiring conditions for older women in entry-level jobs in two cities. A younger worker is more than 40 percent more likely to be offered an interview than is an older worker. No evidence is found to support taste-based discrimination as a reason for this differential, and some suggestive evidence is found to support statistical discrimination (Lahey, 2008).

\subsection{European Globalization Adjustment Fund}

As author mentioned - globalization impact to economic is significant, promotes development and well-being, but at the same time has a negative impact on some processes.

In order to mitigate the negative effects of globalization and lower unemployment, the European Union established the_European Globalization Adjustment Fund in 2006. It aims to provide support to redundant workers who have lost their jobs as a result of globalization (European Globalisation Adjustment Fund buklets EU, 2020).

This exceptional solidarity fund co-finances labour policy to reinhocate workers or set up businesses. Funded projects include education and training, career advice, as well as job search assistance, mentoring and business creation.

In 2009, the Fund was expanded to cover job losses caused by major structural changes caused by the economic and financial crisis (European Globalisation Adjustment Fund buklets EU, 2020).

In April 2021, MPs agreed to update the rules_so that the fund could help more European workers.

Globalization Fund: increase aid for unemployed workers and sources of wage losses.

We evaluate the sources of wage losses of workers displaced due to firm closure by comparison of workers' wages before and after displacement. We decompose the sources of the wage losses into the contribution of firm, match quality, and job title fixed effects. Sorting into lower paying job titles represents the largest component of the monthly wage loss of displaced workers, accounting for 37 percent of the total average monthly wage loss compared to 31 percent for the firm and 32 percent for the match effects. With respect to the hourly wage losses, job title effects account for 46 percent of the total loss, while firm and match effects contribute in equal shares representing each 27 percent of the loss (Felcis \& Felcis, 2021).

The Fund may be used for:

1. where more than 200 workers have been laid off by the same undertaking and its suppliers;

2. if a large number of employees lose their jobs in a particular sector in one or more neighboring regions;

3. to apply for a one-off investment of $€ 22,000$ to start your own business or buy back a business;

4. in order to benefit from special measures, such as a childcare allowance, which is granted to workers caring for children so that they can participate in training or seek employment (European Globalisation Adjustment Fund buklets EU, 2020). 


\subsection{EU rules to prevent the exploitation of workers}

In 2017, Parliament adopted a resolution calling for eu-wide rules requiring textile and clothing suppliers to respect workers' rights. Parliament proposed the introduction of a 'musthave due diligence' system, which means that human rights standards are respected in the production process before a trade agreement is concluded. Production in third countries should comply with EU norms for the production of sustainable and ethical textile products. Parliament also calls on the EU and the Member States to promote the introduction of INTERNATIONAL Labour Organization standards on wages and working hours in partner countries in the garment sector.

The Redistribution and Economist treatments significantly increase support for more progressive income or estate taxes, while the Efficiency treatment has no effect (Stantcheva, 2021).

We consider that large firms involved in the alliance may have distributed decisionmaking structures involving both alliance managers in charge of day-to-day activities and top managers who are responsible for a company's strategic decision making (Ghosh \& Klueter, 2021).

EU rules protect women rights as well. It reduces the social budget expenditure of local governments, while contributing to the overall budget in the form of a labour tax.

Popular expansionary policies - such as accommodative monetary policy - generate a debt-financed short-run boom at the expense of indebted demand in the future. When demand is sufficiently indebted, the economy gets stuck in a debt-driven liquidity trap, or debt trap. Escaping a debt trap requires consideration of less conventional macroeconomic policies, such as those focused on redistribution or those reducing the structural sources of high inequality (Mian et al., 2021).

\subsection{Impact of COVID on globalization}

The new changes introduced by COVID in working conditions provide a good opportunity for entrepreneurs to include in the labour market the part of society that can work in offices, but there are problems with movement, including those who, due to various family reasons, live far from city and parish centers, can include in the labour market employees who need a flexible work schedule due to family reasons or health problems.

The global pandemic caused more than one turnaround in many companies, as well as accelerated the processes of change that had begun a decade ago and even earlier.

We treat health as a form of human capital and hypothesize that women with more human capital face stronger incentives to make costly investments with future payoffs, such as avoiding abusive partners and reducing drug use (Papageorge et al., 2021).

Before the pandemic, we were just talking and looking for different forms of distance work so that the labour market would involve everyone able to work, only adapting the working regime and conditions to different needs of people. After the pandemic, new employment form, remote business management, contracting, updating electronic signatures as well as mobility are the new reality.

The gradual digitalization of the global community has been going on for more decades, but the pandemic was a serious push in the area of the digitalization of services. Most public authorities are able to serve their customers remotely.

At the end of 2019, i.e. before the pandemic, the e-signature procedure for contracting in the company was used by signing one in four contracts in the world, and in 2021. In the first half of the year, the increase in the weight of digital service reached $30.1 \%$. Share of contracts concluded with e-signature on the Latvian market has increased from 25 to $50 \%$

The evaluation of the Ministry of Economics on the impact of remote work on productivity reveals in the long term that approximately $38 \%$ of employees in the Latvian 
economy, depending on the sector and specifics of the position, can potentially work remotely, moreover, the global experience in financing office development and slow solutions confirms that remote forms of work allow to recruit employees from the wider surroundings and also with special needs (Kovalovs, 2021).

Therefore, in general, under the influence of COVID, it has been possible to bring about the changes that social entrepreneurs have already been talking about more quickly since 2018, when the Social Entrepreneurship Law came into force.

Social entrepreneurship partly performs the functions of both private and public and nongovernmental or third sector, so there is no consensus among scientists on its place in the economic sectors (Dobele, 2014).

The impact of the pandemic shows more clearly the importance and role of social entrepreneurship in the overall economy, its contribution. Clearly, time gave a clear answer that social entrepreneurship is one of the types of entrepreneurship, and with a very great contribution - not only to the economy, but also to solving social issues.

The new regional reform will definitely introduce positive changes in Latvia, local governments, calculating the budget, have come to the decisions that it is more economically advantageous to find opportunities to involve everyone who willing and be able to work in the labour market, regardless of the health condition, place of residence and the opportunity to work at certain hours of the day.

Organizational design and anti-corruption policies must balance agency issues at different levels of the hierarchy (Bandiera et al., 2021).

The COVID-19 pandemic has shown that the production of critical sectors and products, such as medicines, needs to be relocated to Europe.

Consequently, manufacturers need to look for solutions to find labour in Europe by relocating production facilities in order not to lose competitiveness.

As a result of COVID, new groups of people in need of support emerged - special work directing, such as people caring for young children or dependent relatives.

At the same time, the COVID pandemic has made it possible to work from home.

Some professions have had to retrain. Also, as a result of globalization, some professions have had to retrain in order to remain in the labour market or not to lose their normal wages.

While the overall results of the liberalization of international trade are positive, it hits some sectors hard and the length of the adjustment period- which is necessary for workers to move to other sectors - is short and situation the iniciate benefits.

Vaccination represents a canonical example of externalities in economics, yet there are few estimates of their magnitudes. I estimate social and externality benefits of influenza vaccination in two settings. First, using a natural experiment, I estimate the impacts of aggregate vaccination rates on mortality and work absences in the United States. Second, I examine a setting with large potential externality benefits: vaccination mandates for healthcare workers. I find that the social benefits of vaccination are substantial, most of benefits operate through an externality, and the benefits of healthcare worker vaccination are particularly large (Raposo et al., 2021).

Weronika Felcis, Elgars Felcis, LU SZF SPPI Female response to pandemic and environmental crises in rural Latvia The overall study explores existing practices in management of common natural resources and co-creating understanding and responses to ongoing environmental breakdown that is increasingly putting pressures on social and economic reality in regions of Latvia. Specifically, the latter was brought to reality of many women by consolidating the usually manageable roles of care providers, house keepers and employees (often also breadwinners) with minors being forced to continue education on a distance and seniors needing special care at this time. This societal arrangement of females being the primary subjects of reproductive work suddenly has put much more pressure on women of all social classes. Women who worked in service-related sectors faced new societal 
risks, for others like women who work in pandemic governing sectors (health care and government) work has intensified and raised emotional and psychological burden. The research, based in feminist political ecology approach and triangulated quantitative and qualitative methods of data gathering, analyzes changing lifestyles of women in 5 rural regions of Latvia - how do they respond to this crisis, how they reflect on doing gender at their homes and whether the vastly complimented achievements of four waves of feminism changed anything in life of women in rural Latvia? Or are they rather pushed back with means of toxic femininity to traditional gender roles in times of crisis, struggling with specifically Latvian toxic masculinity at the same time (Lahey, 2008). It will also show the first results from representative survey conducted in the study in 2020 (Felcis \& Felcis, 2021).

Both globalization and the COVID pandemic have both positive and negative impacts on processes, everyday life and the economy as a whole. As a solution to stop the pandemic, at least to contain it, scientists have developed vaccines that protect against infection and infection from a severe disease course or even fatal outcome. But the problem is people's attitude to vaccination. Anti-vaccineers spread a lot of information about the bad consequences of vaccines. Studies show that most anti-vaccines are people with low levels of education, hence the basically the less skilled workforce (SKDS pētijums, 2021). This poses some problems for companies that are basically employed by low-skilled workers, because as of 1 October 2021 employers will be able to dismiss unvaccinated workers, which will lead to even greater labour shortages. In a situation where the labour market is changing a lot: modern technologies allow for a reduction in manual labour while requiring welleducated workers, less skilled workers are increasingly to be unemployed.

\section{Conclusions, proposals}

The study shows that the impact of globalization on social entrepreneurship varies from one EU country to another. Globalization has had a greater impact on those countries where independence has been regained recently and on small countries in terms of population.

Under the influence of COVID, new groups of people have appeared who need a special working regime. (Take care small children and schoolchildren)

Both globalization and the COVID pandemic have both positive and negative impacts on processes, everyday life and the economy as a whole.

Covid time has shown and proved an opportunity for working with flexible working hours and a distance working.

Globalization and international trade also affect human rights, so EU trade policy includes instruments to protect them.

The impact of COVID on the formation and development of social enterprises is very large, because:

1. It has been proven that employees of almost all types of companies can work remotely, there is no need to be on site every day in offices.

2. The lack of labour resources has contributed to the employment of people with special needs.

3. The social burden on state and local authorities is too great to cope without the support of entrepreneurs. Therefore, state and local government institutions are increasingly open to dialogue, which promotes the development of social entrepreneurship not only in Latvia and Europe, but all over the world.

4. The workforce needed in the production facilities was less educated, foreign companies, based on their experience, created jobs for people with special needs, it was a good example for our entrepreneurs how to involve people with short needs in the labour market. 
5. Both globalization and the COVID pandemic have both positive and negative impacts on processes, everyday life and the economy as a whole.

6. Although COVID has a negative impact on economic development in general, it raises awareness of the importance of labour resources, provides an opportunity to assess the importance of globalization and look at processes from a different perspective. When solving problems and making plans from a different perspective, we are seeing a faster change in the situation, organization of work and processes, which will undoubtedly contribute to faster development in the future.

7. The COVID pandemic has demonstrated the unity not only of Europa's, but of the whole world, how connected we are to each other, how many new technologies and their rapid development have blurred the boundaries between both industries and countries.

8. If before the pandemic there were major problems in establishing dialogues between social entrepreneurs and state/local government institutions, although the importance and contribution of social entrepreneurship was explained with examples from the experience of other countries, then this year a lot of negotiations and projects have been launched that would promote the development of social entrepreneurship in Latvia, taking into account the experience of other countries.

\section{References}

1. Bandiera, O., Best, M. C., Khan, A. Q., \& Prat, A. (2021). The allocation of authority in organizations: A field experiment with bureaucrats. The Quarterly Journal of Economics, 136(4), 2195-2242.

2. Bettinazzi, E. L., \& Zollo, M. (2021) Stakeholder orientation and experiential learning: Evidence from corporate acquisitions. Journal of Management Studies.

3. Bornstein, D. (2007). How to change the world: Social entrepreneurs and the power of new ideas. Oxford University Press.

4. Dobele, L. (2014). Social business opportunities in Latvia. SIA Drukātava, 470.

5. European Globalisation Adjustment Fund buklets EU. (2020). Retrieved from: https://ec.europa.eu/social/main.jsp?langId=en\&catId=326

6. Felcis, V., Felcis, E. (2021). LU SZF SPPI Female response to pandemic and environmental crises in rural Latvia. Sociology in Latvia: latest research, retrieved from: http://dspace.lu.lv/dspace/bitstream/handle/7/56477/LU 79konf_Sociologijas_sekcija 2 021.pdf?sequence $=1$

7. Ghosh, A., \& Klueter, T. (2021). Top Management and Alliance Terminations: An Information Processing Perspective. Journal of Management Studies.

8. Jeromanova-Maura, M. S., \& Sukjurovs, M. I. (2019). Social Entrepreneurship as One of the Business Development Activities in Rural Areas of Latvia. In Proceedings of the 12th International Scientific and Practical Conference. Volume I (Vol. 86, p. 91).

9. Jeromanova-Maura, S., Zvirgzdina, R., \& Linina, I. (2018). Development of social entrepreneurship in Latvia. In Globalization and its socio-economic consequences (No. 3 , pp. 1120-1126).

10. Kovalıovs, A. (2021). Jauns laikmets - jauni izaicinājumi. Forbes Nr.24 2021. gada septembris 21.-22.lpp. 
11. Laajaj, R., \& Macours, K. (2021). Measuring skills in developing countries. Journal of Human resources, 56(4), 1254-1295.

12. Lahey, J. N. (2008). Age, women, and hiring an experimental study. Journal of Human resources, 43(1), 30-56.

13. Mian, A., Straub, L., \& Sufi, A. (2021). Indebted demand. The Quarterly Journal of Economics, 136(4), 2243-2307.

14. Papageorge, N. W., Pauley, G. C., Cohen, M., Wilson, T. E., Hamilton, B. H., \& Pollak, R. A. (2021). Health, human capital, and domestic violence. Journal of Human Resources, 56(4), 997-1030.

15. Raposo, P., Portugal, P., \& Carneiro, A. (2021). The Sources of the Wage Losses of Displaced Workers The Role of the Reallocation of Workers into Firms, Matches, and Job Titles. Journal of Human Resources, 56(3), 786-820.

16. SKDS pētijums. (2021). Retrieved from: https://www.skds.lv/

17. Stantcheva, S. (2021). Understanding tax policy: How do people reason?. The Quarterly Journal of Economics, 136(4), 2309-2369.

18. Strautins, P. (2020). Luminor ekonomikas globalizācijas apskats 2020. Retrieved from: https://www.luminor.lv/lv/ekonomikas-apskati

19. Z̄ilīte, L. (2013). Personāla vadība un socionika. Rīga: Biznesa Augstskola Turība, 304.

20. White, C. (2021). Measuring social and externality benefits of influenza vaccination. Journal of Human Resources, 56(3), 749-785. 